\title{
Suppression of lymphangiogenesis in human lymphatic endothelial cells by simultaneously blocking VEGF-C and VEGF-D/VEGFR-3 with norcantharidin
}

\author{
ZHONG-YAN LIU ${ }^{1 *}$, HAI-OU QIU ${ }^{2 *}$, XIAO-JIAN YUAN ${ }^{1 *}$, YAN-YAN NI $^{1}$, \\ JIAN-JUN SUN ${ }^{1}$, WEI JING ${ }^{1}$ and YUE-ZU FAN ${ }^{1}$
}

Departments of ${ }^{1}$ Surgery and ${ }^{2}$ Otolaryngology, Tongji Hospital, Tongji University School of Medicine, Shanghai, P.R. China

Received May 23, 2012; Accepted July 20, 2012

DOI: 10.3892/ijo.2012.1603

\begin{abstract}
Lymph node metastasis of tumors is a crucial early step in the metastatic process. Tumor lymphangiogenesis plays an important role in promoting tumor metastasis to regional lymph nodes. Norcantharidin (NCTD) has been reported to possess potent anti-angiogenesis and antitumor properties in several cell lines and xenograft tumor models. However, its role in tumorassociated lymphangiogenesis and lymphatic metastasis remains unclear. Here, we investigated the effect of NCTD on proliferation, apoptosis, migration, invasion and the lymphatic tube formation, lymphangiogenesis, of human lymphatic endothelial cells (HLECs) in vitro by MTT, proliferation assay, Hoechst staining and flow cytometry, scraping line method, Matrigel invasion assay, inverted or fluorescence microscope and transmission electron microscope. Moreover, the underlying mechanisms, such as VEGF-C, VEGF-D, VEGFR-3 at protein and mRNA levels in lymphangiogenesis using 3-dimensional (3-D) culture of HLECs were measured by immunohistochemistry, western blotting and real-time polymerase chain reaction (RT-PCR). It was shown that NCTD inhibited proliferation, migration, invasion and lymphatic tube formation (forming-lymphatic and/ or formed-lymphatic) of HLECs, induced HLEC apoptosis (all $\mathrm{P}<0.01)$ significantly, in a dose- and time-dependent manner $\left(\mathrm{IC}_{50} 6.8 \mu \mathrm{g} / \mathrm{ml}\right)$; and downregulated the expression of VEGF-C, VEGF-D and VEGFR-3 at protein or/and mRNA levels $(\mathrm{P}<0.01)$ in HLEC lymphatic tube formation. Thus, we identified for the first time that NCTD inhibited HLEC lymphangiogenesis by simultaneously blocking VEGF-C and VEGF-D/VEGFR-3 in vitro. The present findings may be of importance to explore the therapeutical target or strategy of NCTD for tumor lymphangiogenesis and lymphatic metastasis.
\end{abstract}

Correspondence to: Professor Yue-Zu Fan, Department of Surgery, Tongji Hospital, Tongji University School of Medicine, 389 Xincun Road, Shanghai, P.R. China

E-mail: fanyuezu_shtj@yahoo.com.cn

*Contributed equally

Key words: human lymphatic endothelial cell, lymphangiogenesis, 3-dimensional culture, norcantharidin, antilymphangiogenic therapy

\section{Introduction}

Metastatic spread of tumor cells is the most lethal aspect of cancer and often occurs via the lymphatic vessels (1). Tumor-associated lymphatic vessels, also referred to as tumor lymphangiogenesis (2), i.e., new lymphatic vessel formation in cancer (3), act as a conduit by which disseminating tumor cells access regional lymph nodes and form metastases $(4,5)$. Lymphangiogenic growth factors, which include the secreted glycoproteins vascular endothelial growth factor-C (VEGF-C), vascular endothelial growth factor-D (VEGF-D) and their cognate receptor tyrosine kinase vascular endothelial growth factor receptor-3 (VEGFR-3) located on lymphatic endothelial cells can advance or regulate proliferation, migration, metastasis and survival of lymphatic endothelial cells (LECs), and lymphatic tube formation in physiological and pathological conditions such as wound repair, tissue regeneration and tumorigenesis (6-8). These molecules play an important role on lymphangiogenesis and metastatic spread of tumor cells to lymph nodes $(9,10)$. So, a targeted approach to block lymphangiogenesis pathways, such as VEGF-C, or/and -D/VEGFR-3 axis, seems to be an attractive anticancer treatment strategy.

Norcantharidin (NCTD), a demethylated form of cantharidin with anti-tumor properties and an active ingredient of traditional Chinese medicine-Mylabris, has been reported to possess potent antiangiogenesis and antitumor properties in several cell lines and tumor xenograft models (11-16). However, its role in tumor-associated lymphangiogenesis and lymphatic metastasis remains unclear. Here, we investigated for the first time the effect of NCTD on proliferation, migration, tube-formation, i.e., lymphangiogenesis of human lymphatic endothelial cells (HLECs), and their VEGF-C or/and -D/VEGFR-3 pathways in vitro, so as to explore wether it served as a target inhibitor for the HLEC lymphangiogenesis and whether it is a potential antilymphangiogenic agent of cancer therapeutic strategy.

\section{Materials and methods}

Cell lines and cell culture. HLECs used in this study were human dermal lymphatic endothelial cells (HDLECs). Primary HDLECs were purchased from ScienCell Research Laboratories, USA, and were identified by using immunofluorescent cyto- 
chemical technique via $\mathrm{CD}_{31}$, podoplanin and Lyve1. Tissue culture flasks were peridiumed with fibronectin $(1 \mathrm{mg} / \mathrm{ml}$; Chemicon, USA). Cells were cultured in endothelial cell growth medium (ECGM) with endothelial cell growth factor (ScienCell Research Laboratories) in an incubator (Forma Series II HEPA Class 100, Thermo Co., USA) with $5 \% \mathrm{CO}_{2}$ at $37^{\circ} \mathrm{C}$. The medium was changed every 2 days. When the cells became confluent, at $80 \%$ plating efficiency, they were treated with $5 \mathrm{ml}$ phosphate-buffered saline (PBS) solution, digested with $1 \mathrm{ml} 0.025 \%$ trypsin and $1 \mathrm{ml} 0.02 \%$ ethylenediamine tetraacetic acid (EDTA) solution (ScienCell Research Laboratories), and observed by inversion microscope (Nikon TS100, Japan). Then the cells were retuned to culture at $37^{\circ} \mathrm{C}$ in $5 \% \mathrm{CO}_{2}$, and continued transfer of culture. The cells, which were at fifth generation, were used in the experiment.

Proliferation assay. The cultured HDLEC suspensions $\left(5 \times 10^{5}\right.$ cells $/ \mathrm{ml}$ ) were used in this assay. The cultures were divided into NCTD groups and control groups. The tetrazoliumbased colorimetric assay (MTT) was used to evaluate the inhibitory effect of NCTD on proliferation of HDLECs in vitro (tumor cytotoxicity test). After HDLECs were cultured in a 96 -well plate peridiumed with fibronectin $\left(5 \times 10^{4}\right.$ cells/ $\mathrm{ml} \times 100 \mu \mathrm{l} /$ well) in culture medium (ECGM, $100 \mu \mathrm{l} /$ well) overnight, they were without (negative control, equal ECGM solution) or treated with various concentrations (1.25-80 $\mu \mathrm{g} / \mathrm{ml}$, experimental groups; 6 wells per concentration) of NCTD (10 mg/2 ml, Jiangsu Kangxi Pharmaceutical Works, China) in fresh culture medium at $37^{\circ} \mathrm{C}$ in $5 \% \mathrm{CO}_{2}$ for 24 h. The tumor cell cytotoxicity was determined by MTT (methyltiazolyl tetrazolium, Sigma, MO, USA). The optical densities (A value) at $490 \mathrm{~nm}$ were measured with an ELISA reader (Elx800UV, Bio-Tek Co., USA). The A490 value of the experimental groups was divided by the A490 value of untreated controls and presented as a percentage of the cells. The inhibitory percent of NCTD on HDLECs $(\%)=(1-\mathrm{A} 490$ value in the experimental group / A490 value of control group) $x 100 \%$. Three separate experiments were performed. The concentration of drug giving $50 \%$ growth inhibition $\left(\mathrm{IC}_{50}\right)$ was calculated from the formula $\mathrm{IC}_{50}=\lg ^{-1}\{\mathrm{Xm}-\mathrm{I}[\mathrm{P}-(3-$ Pm-Pn)/4]\}. In equal experimental conditions, HDLECs were treated with $5 \mu \mathrm{g} / \mathrm{ml}$ concentration of NCTD at 6 -h interval for $48 \mathrm{~h}$, the optical densities (A value) and the inhibitory percent of NCTD on HDLECs were measured and calculated.

Apoptosis assay. HDLECs $\left(1 \times 10^{5}\right.$ cells $\left./ \mathrm{ml}\right)$ were cultured on the fibronectin-peridium slides in a 96 -well plate overnight. When slides were filled with $50-80 \%$ cells, they were treated without (negative control, equal ECGM solution) or treated with various concentrations $(1.25-10 \mu \mathrm{g} / \mathrm{ml}$, experimental groups) of NCTD, respectively. Then, the slides were fixed with $0.5 \mathrm{ml} 4 \%$ formalin, washed with PBS solution, and stained with $0.5 \mathrm{ml}$ fluorescence agent Hoechst 33258 (Sigma) and CY3 NHS ester (Lumiprobe, USA). Apoptosis of HDLECs was observed under a fluorescence microscope (Nikon Eclipse TE2000-U, Japan). Ten sample slides in each group were chosen by analysis. Visual fields $(>10)$ were observed or $>500$ cells were counted per slide. The apoptotic percent of each group $=$ apoptotic cells/cells in all $\mathrm{x} 100 \%$.
Flow cytometry. HDLECs $\left(1 \times 10^{5}\right.$ cells/ml) cultured in a 96-well plate peridiumed with fibronectin were without (negative control, equal ECGM solution) or treated with various concentrations $(1.25-15.00 \mu \mathrm{g} / \mathrm{ml}$, experimental groups; 6 wells per concentration) of NCTD at $37^{\circ} \mathrm{C}$ in $5 \% \mathrm{CO}_{2}$ for $24 \mathrm{~h}$, then were made up into the cell suspension $\left(5 \times 10^{5}\right.$ cells $\left./ \mathrm{ml}\right)$, and suspended in $500 \mu \mathrm{l}$ binding buffer. Tumor DNA was then stained for $15 \mathrm{~min}$ with $5 \mu \mathrm{l}$ Annexin V-FITL and propidium iodine (PI, Sigma). DNA value and apoptotic rate of HDLECs in each group were determined by Cell Apoptotic Detection Kit (BioDev Co., China) and Fluorescent Activated Cell Sorter (420 type FACS flow cytometry, Becton-Dickinson, CA).

Morphological observation. HDLECs ( $1 \times 10^{5}$ cells $\left./ \mathrm{ml}\right)$ cultured in a 96-well plate peridiumed with fibronectin overnight were without (negative control, equal ECGM solution) or treated with various concentrations $(1.25-5.00 \mu \mathrm{g} / \mathrm{ml}$, experimental groups; 6 wells per concentration) of NCTD for $24 \mathrm{~h}$, and then observed under an inverted microscope (Ix50/Ix70, Olympus, Japan). Simultaneously in the control group and $2.50 \mu \mathrm{g} / \mathrm{ml}$ NCTD group, they were digested with $0.025 \%$ trypsin and $0.002 \%$ EDTA solution, centrifuged (200 g for $10 \mathrm{~min}$ ), washed with PBS solution, and fixed in $2.5 \%$ glutaraldehyde-1\% osmium tetroxide buffered with PBS ( $\mathrm{pH}$ 7.2). The specimens were dehydrated in a graded ethanol series, embedded in Spury Resin, cut into 50-70 nm sections, double-stained with uranyl acetate-lead citrate, and analyzed by standard procedures under a transmission electron microscope (JEM-1230, Jeol Co., Japan).

Migration assay. The cultured HDLECs were inoculated in 4 culture dishes peridiumed with fibronectin $\left(1 \times 10^{5}\right.$ cells $/ \mathrm{ml}$ $\mathrm{x} 100 \mu \mathrm{l} / \mathrm{dish}$ ) in fresh culture medium (ECGM, $100 \mu \mathrm{l} / \mathrm{dish}$ ). When HDLECs were fused into a single layer in dishes, a straight line on the surface of the growthing cells was scraped with sterile blades by scraping line method. Then, the cells at side of the line were scraped off completely using a plastic scraper, washed with D-Hanks. The cultures were treated without (negative control, equal ECGM solution) or treated with various concentrations (1.25-5 $\mu \mathrm{g} / \mathrm{ml}$, experimental groups, 4 dishes per concentration) of NCTD in fresh culture medium at $37^{\circ} \mathrm{C}$ in $5 \% \mathrm{CO}_{2}$ for $24 \mathrm{~h}$. Lastly, cell migration distance onto the scraped areas and migrating cells were measured and counted in 4 independent microscopic visual fields (x100) under inversion microscope (Nikon TS100, Japan), and expressed as mean number per 1 field, so as to determine the inhibitory effect of NCTD on proliferation and migration of HDLECs.

Invasion assay. Living HDLECs were trypsinized with $0.25 \%$ trypsin and washed with fresh culture medium, suspended in the culture medium with $10 \%$ bovine calf serum $\left(1 \times 10^{5}\right.$ cells/ $\mathrm{ml})$. The cell suspension was transferred to the above layer of the Matrigel invasion chamber $(0.3 \mathrm{ml} /$ every chamber $)$, while $0.8 \mathrm{ml}$ of RPMI-1640 medium with $10 \%$ bovine calf serum was only added to the bottom layer of the Matrigel invasion chamber. Then the cells were cultured in $50 \mathrm{ml} / 1 \mathrm{CO}_{2}$ at $37^{\circ} \mathrm{C}$ for $24 \mathrm{~h}$. The cells were treated without (untreated control group) or with various concentrations of NCTD (the six-concentration groups, every concentration $\mathrm{x} 6)$ in fresh culture medium $(0.3 \mathrm{ml} /$ every chamber), were cultured in an incubator with $50 \mathrm{ml} / 1$ at $37^{\circ} \mathrm{C}$ for $72 \mathrm{~h}$. The passing-membrane cells were collected from 
the above layer of the Matrigel invasion chamber, centrifuged (200 r/min, $10 \mathrm{~min}$ ), dyed by trypan blue dye, and counted in a hemocytometer. Each experiment was performed thrice.

Lymphatic tube formation assay. First, the mixed fibrinogen gel was prepared with fibrin gel [which was from human fibrinogen ( $3 \mathrm{mg} / \mathrm{ml}$; Bite Bio Co., Beijing, China) and human thrombin (50 U/ml; Sigma) dissolved with PBS], solidified by adding in order $500 \mu \mathrm{l}$ fibrinogen, $100 \mu \mathrm{l}$ ECGM and $10 \mu \mathrm{l}$ thrombin solution, and incubated at $37^{\circ} \mathrm{C}$ in $5 \% \mathrm{CO}_{2}$ for $30 \mathrm{~min}$ to promote gelling, according to the literature. Then, 6 -well plates were coated with the fibrinogen gel $(0.05 \mathrm{ml} /$ well $)$ and incubated at $37^{\circ} \mathrm{C}$ for $1 \mathrm{~h}$ to promote gelling. HDLECs (5th-generation cells) suspension $\left(1 \times 10^{5} / \mathrm{ml}, 300 \mu \mathrm{l} /\right.$ well $)$ were seeded on the gel surface, cultured in ECGM (2 ml) in an incubator with $5 \% \mathrm{CO}_{2}$ at $37^{\circ} \mathrm{C}$. The medium was changed every 2 days. After 1 week, the cells were treated without (equal ECGM solution; the control group) or with $2.5 \mu \mathrm{g} / \mathrm{ml} \mathrm{NCTD}, 100 \mu 1 \mathrm{mF} 4-31 \mathrm{Cl}$ (a soluble VEGFR-3 antibody) and NCTD+mF4-31C1 (experimental groups, 6/each group), respectively, for 2-4 days. Inverted phasecontrast light microscope (Olympus) was used to observe and record the morphological changes between the groups and the tube formation by HUVECs, i.e., lymphangiogenesis in vitro. Tube formation ability was quantified by counting the total number of cell clusters and branching in 5 randomly chosen microscopic fields per well under magnification x100. Results were expressed as the mean percentage of branching over total cell clusters and expressed as a ratio to the control.

Immunocytochemistry. HDLEC suspension $\left(3 \times 10^{5}\right.$ cells $/ \mathrm{ml}$, $400 \mu \mathrm{l} /$ well) was seeded on the fibronectin-peridium slides in a 96-well plate overnight, cultured continually for $48 \mathrm{~h}$. When cells were fused into a single layer, they were treated without (equal ECGM solution; the control group) or treated for $24 \mathrm{~h}$ with $2.5 \mu \mathrm{g} / \mathrm{ml}$ NCTD, $100 \mu \mathrm{lmF} 4-31 \mathrm{C} 1$ (a soluble VEGFR-3 antibody), and NCTD+mF4-31C1, respectively. Then, the slides were fixed with the solution of methanol and acetone $(\mathrm{v} / \mathrm{v}=1: 1)$, were used in the experiment.

VEGF-C, VEGF-D, VEGFR-3 protein products from HDLECs of each group were determined by streparidinperoxidase (S-P) staining method, according to the kit brochure (Jinmei Biotechnology Co., Ltd., Shanghai). The slides from each group were washed with PBS solution, treated with $3 \%$ $\mathrm{H}_{2} \mathrm{O}_{2}$ and $1 \%$ TritonX-100 solution, were added in order with $\mathrm{A}$ reagents, i.e., primary antibody [rabbit anti-human monoclonal antibody VEGF-C (invitrogen, USA), VEGF-D (Abcam, USA), VEGFR-3 (Cell Signaling, USA)], B reagent (biotinylated anti-rabbit secondary), C reagent (HRP logo Streptavidin) and DAB solution, respectively. Then, slides were rinsed in distilled water, dehydrated through alcohol and xylene and mounted coverslip using a permanent mount medium and observed by optic microscope (Olympus). For negative control, the slides were treated with PBS in place of primary antibody. Six sample slides in each group were chosen by analysis. Visual fields $(>10)$ were observed or $>500$ cells were counted per slide.

Western blot analysis. The drug experiment for HDLECs in vitro was the same as for immunocytochemistry. Expression of VEGF-C, VEGF-D, VEGFR3 proteins from HDLECs of each group were determined by western blot analysis (Lowry method; Lowry method protein kit, Puli Lai Co., Shanghai, China). Cells were lysed with $200 \mathrm{ml}$ of cell lysis buffer (Promega) containing a cocktail of protease inhibitors (Nacalai Tesque) and the supernatant of the lysed cells was recovered. An aliquot of $20 \mathrm{mg}$ of proteins was subjected to sodium dodecyl sulfate-polyacrylamide gel electrophoresis (SDS-PAGE) under reducing condition, and were then transferred to a PVDF membrane. One hour after being blocked with PBS containing 5\% non-fat milk, the membrane was incubated overnight, was then added in order with each primary antibody [(rabbit anti-human VEGF-C, VEGF-D, VEGFR-3 antibodys (1:500; Abcam), and rabbit anti-human $\beta$-actin antibody (1:5000; Cell Signaling, USA)] diluted with PBST containing 5\% non-fat milk at $4^{\circ} \mathrm{C}$, an appropriate anti-rabbit HRP-labeled secondary antibody (1:5000; Abcam), HistoFine (Dako, Glostrup, Denmark) at room temperature for $2 \mathrm{~h}$. The target proteins were visualized by an enhanced chemiluminescent (ECL) reagent (GE Healthcare, USA), imaged on the Bio-Rad chemiluminescence imager. The gray value and gray coefficient ratio of each protein was analyzed and calculated.

RT-PCR analysis. The drug experiment for HDLECs in vitro was the same as immunocytochemistry. Expression of VEGF-C, VEGF-D, VEGFR3 mRNAs from HDLECs of each group were determined by quantitative real-time polymerase chain reaction (QRT-PCR) assay. QRT-PCR was performed as described by the manufacturer. Total RNA was extracted from HDLECs using the TRIzol reagent. Concentration of RNA was determined by the absorption at 260 . The primers for amplification were designed and synthesized by Shanghai Sangon Co. The primers for VEGF-C, VEGF-D, VEGFR3 and GAPDH were as follows: VEGF-C (106 bp) 5'AGT CGC GAC AAA CAC CTT CT3' (sense), 5'GTA GCT CGT GCT GGT GTT CA3' (anti-sense); VEGF-D (194 bp) 5'CAG TGG GTT GAT CTG GGA CT3' (sense), 5'CAT GCA GGG TAG GAT GGT CT3' (anti-sense); VEGFR-3 (117 bp) 5'CGG CTT CAG CTG TAA AGG AC3' (sense), 5' TTG TAA AAC ACC TGG CCT CC3' (anti-sense); GAPDH (128 bp) 5'GCC TCC AAG GAG TAA GAC CC3' (sense), 5'TGT GAG GAG GGG AGA TTC AG3' (anti-sense). Polymerse chain reactions were performed in a $20-\mu 1$ reaction volume. RT-PCR reaction was run in the following conditions: at $94^{\circ} \mathrm{C}$ for $5 \mathrm{~min}$; at $94^{\circ} \mathrm{C}$ for $30 \mathrm{sec}$, at $55^{\circ} \mathrm{C}$ for $30 \mathrm{sec}$, at $72^{\circ} \mathrm{C}$ for $30 \mathrm{sec}, 35$ circles; at $72^{\circ} \mathrm{C}$ for $10 \mathrm{~min}$. The amplifying conditions were control group: at $50^{\circ} \mathrm{C}$ for $2 \mathrm{~min}$, NCTD group: at $95^{\circ} \mathrm{C}$ for $5 \mathrm{~min}, \mathrm{mF} 4-31 \mathrm{C} 1$ group: at $95^{\circ} \mathrm{C}$ for $45 \mathrm{sec}$, and NCTD+mF4-31C1 group: at $60^{\circ} \mathrm{C}, 45 \mathrm{sec} ; 40$ circles. PCR products $(10 \mu \mathrm{l})$ were placed onto $15 \mathrm{~g} / \mathrm{l}$ agarose gel and observed by EB (ethidium bromide) staining using the ABI PRISM 7300 SDS software.

Statistical analysis. Statistical analyses were performed using SPSS 13.0. The data are presented as mean \pm SD. Statistical differences were evaluated using Student's t-test or the $\chi^{2}$ test. $\mathrm{P}<0.05$ was considered statistically significant.

\section{Results}

NCTD inhibits HLEC proliferation. As shown in Fig. 1, the cultured HDLECs began to grow at $6 \mathrm{~h}$, maturated at $24 \mathrm{~h}$, which were predominantly of shuttle-shape, or accumulation, 
A

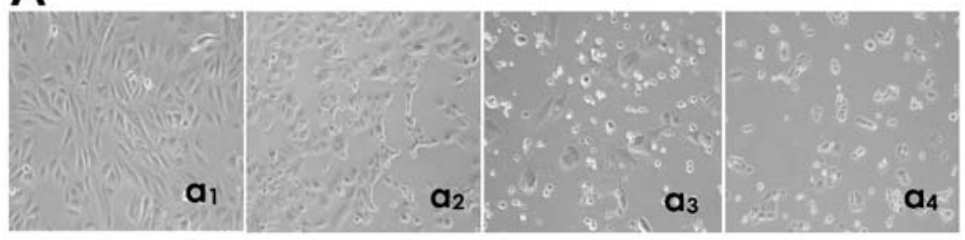

B
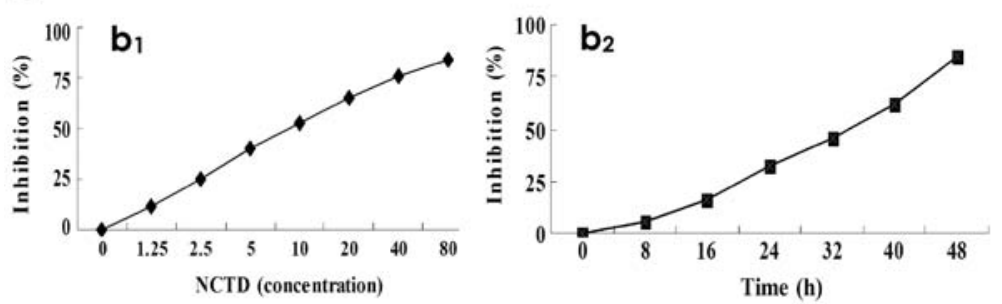

Figure 1. Inhibitory effects of NCTD on HDLEC proliferation in vitro. (A) Histomorphology of HDLECs under inversion optic microscope (magnification x200) at $24 \mathrm{~h}$, such as predominantly shuttle-shape, with abundant cytoplasm, clear nuclei in the control group (a1); visible cell aggregation, floating, nuclear condensation, chromatin redistributing, nuclear fragmentation, cataclysm, apoptotic bodies, or even death in different concentration groups of NCTD (a2, NCTD 1.25 $\mu \mathrm{g} / \mathrm{ml}$; a3, NCTD $2.5 \mu \mathrm{g} / \mathrm{ml}$; a4, NCTD $7.5 \mu \mathrm{g} / \mathrm{ml}$ ). (B) The dose (b1)-, and time (b2)-response curves of NCTD effect on HDLECs with the IC $\mathrm{I}_{50}$ value of $6.8 \mu \mathrm{g} / \mathrm{ml}$. Cell number was counted by the MTT method.

A
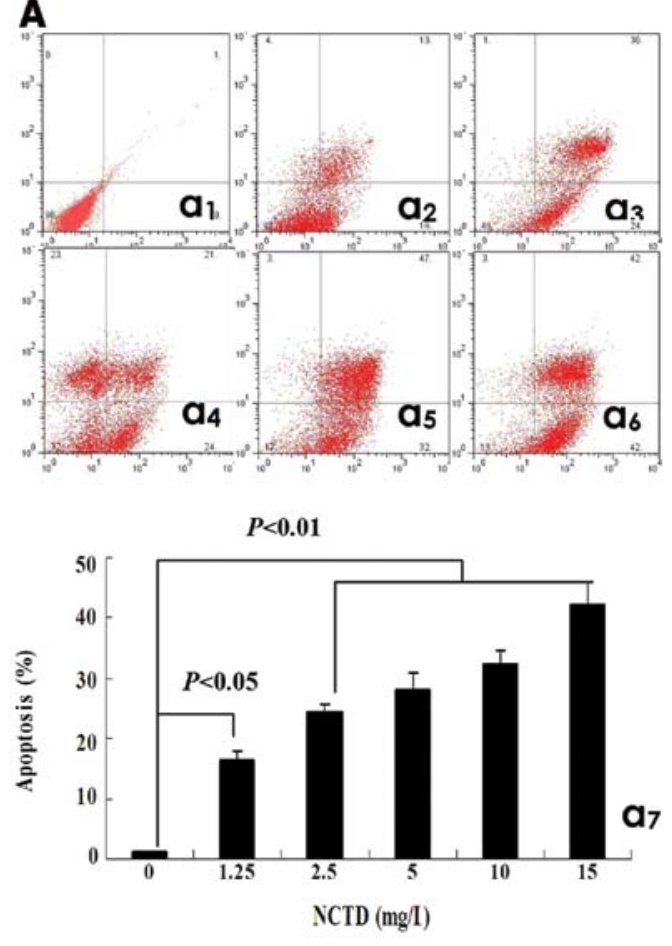

B
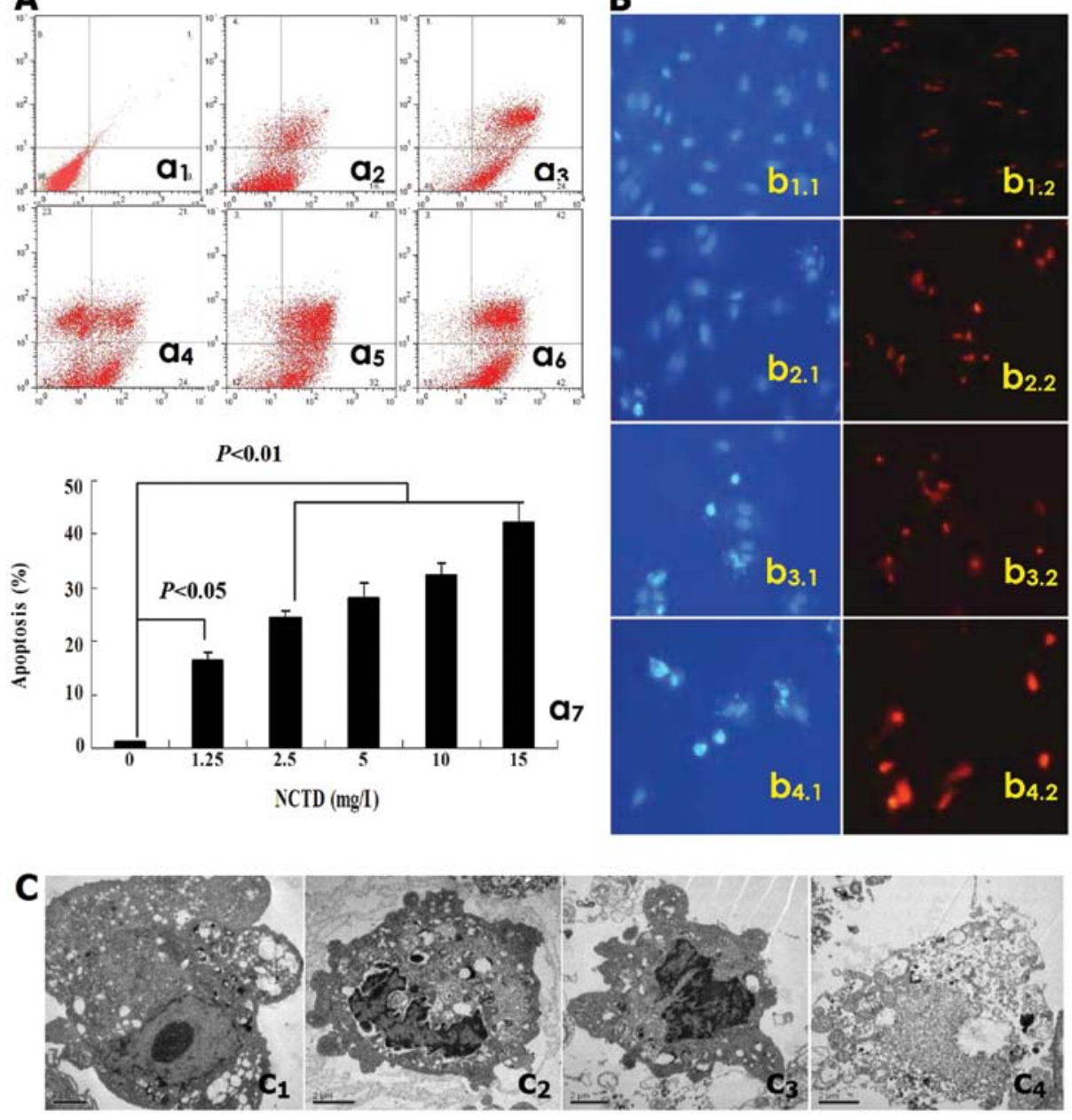

Figure 2. Inductive effect of NCTD on HDLECs apoptosis in vitro. (A) a1, control group; a2-a6, NCTD groups, i.e., a2, $1.25 \mu \mathrm{g} / \mathrm{ml}$; a3, $2.5 \mu \mathrm{g} / \mathrm{ml}$; a4, $5.0 \mu \mathrm{g} /$ $\mathrm{ml} ; \mathrm{a} 5,10 \mu \mathrm{g} / \mathrm{ml} ; \mathrm{a} 6,15 \mu \mathrm{g} / \mathrm{ml}$. a7, the effect of NCTD on HDLECs' apoptosis; FCM analysis. NCTD induced significantly HDLEC apoptosis when compared with control group. (B) b1, control group; b2, NCTD $1.25 \mu \mathrm{g} / \mathrm{ml}$; b3, NCTD $5.0 \mu \mathrm{g} / \mathrm{ml}$; b4, NCTD $10 \mu \mathrm{g} / \mathrm{ml}$; Hoechst and cy3 dye, fluorescent microscope x200. Many cells with normal blue- (b1.1) or brown-dye (b1.2) nuclei, without apoptosis in control group; but with increase of NCTD concentration, viable HDLECs decreased, apoptotic cells which presented bright blue-dye (b2.1-b4.1) or orange-dye (b2.2-b4.2), even with fine or fragmented nuclei increased (b2.1-b4.1). (C) NCTD $2.5 \mu \mathrm{g} / \mathrm{ml}$; transmission electron microscope x8000. Irregular cells with abundant microvilli, clear organelles, larger nucleus/cytoplast ratio, irregular nuclei and chromatin enrichment in control group (c1); and microvilli decreasing, golgiosome atrophy, mitochondria swelling, cytoplast vacuole, nuclear shrinkage, chromosome condensation, chromatin aggregation and typical apoptosis bodies in NCTD group (c2-c4). 
A
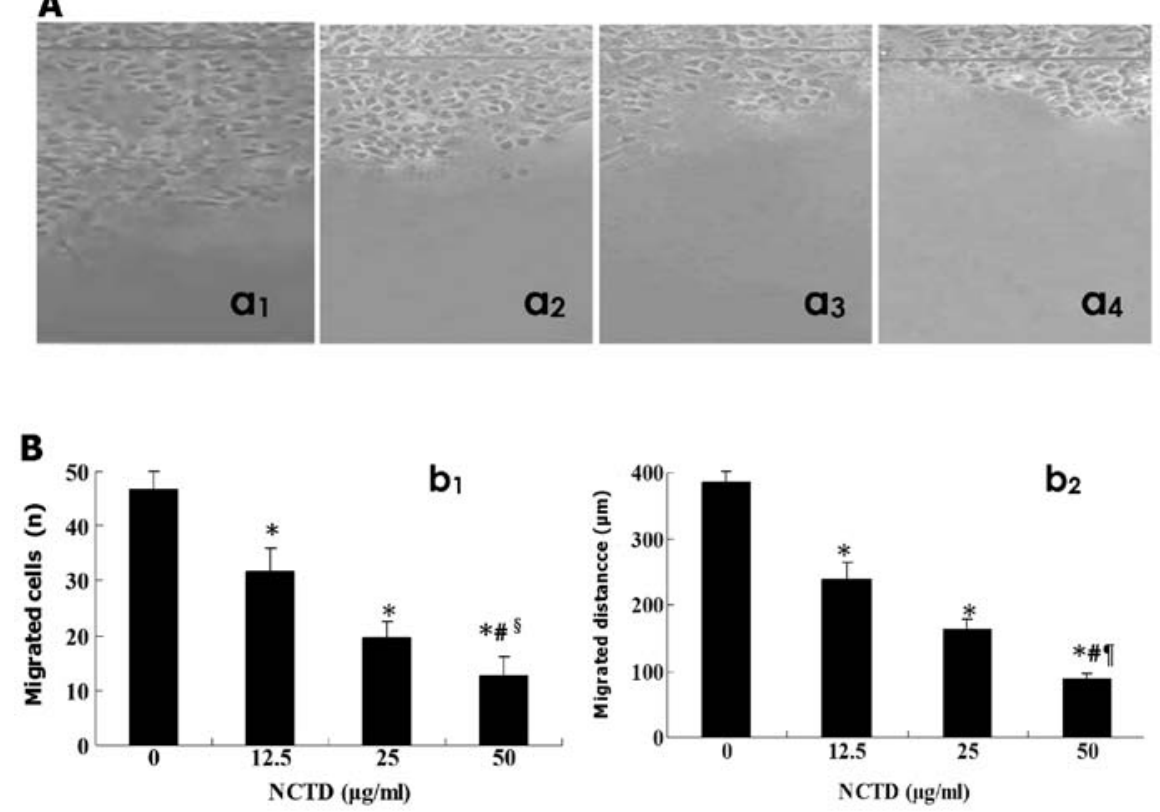

Figure 3. Inhibitory effect of NCTD on HDLEC migration in vitro. (A) Migration assay of HDLECs by scraping line method under an inversion optic microscope, magnification x200 (a1, control group; a2, $1.25 \mathrm{NCTD} \mu \mathrm{g} / \mathrm{ml} ; \mathrm{a} 3,2.5 \mathrm{NCTD} \mu \mathrm{g} / \mathrm{ml} ; \mathrm{a} 4,5.0 \mathrm{NCTD} \mu \mathrm{g} / \mathrm{ml})$. (B) The effect of NCTD on HDLEC migration (b1, migrated cells onto the scraped areas; b2, migration distance of cells onto the scraped areas in different groups). NCTD inhibited significantly HDLEC migration when compared with control group. ${ }^{*} \mathrm{P}=0.000$, vs. control group; ${ }^{\#} \mathrm{P}=0.000$, vs. $1.25 \mu \mathrm{g} / \mathrm{ml}$ NCTD group; ${ }^{8} \mathrm{P}=0.015 ;{ }^{9} \mathrm{P}=0.034$, vs. $2.5 \mu \mathrm{g} / \mathrm{ml} \mathrm{NCTD}$ group.

with abundant cytoplasm, clear nuclei (control group, Fig. 1Aa1); after NCTD treatment, the morphology of HDLECs showed visible cell aggregation, floating, nuclear condensation or fragmentation, cataclysm, apoptotic bodies, or even death (Fig. 1Aa2-a4). Furthermore, NCTD inhibited markedly the HDLEC proliferation in a dose- and time-dependent manner with the $\mathrm{IC}_{50}$ value $6.8 \mu \mathrm{g} / \mathrm{ml}$ (Fig. 1B). Thus, NCTD inhibits significantly the proliferation and growth of HLECs.

NCTD induces HLEC apoptosis. In this study, apoptosis of HLECs was evaluated by flow cytometry (FCM), Hoechst immunofluorescence dye and transmission electron microscopy. As shown in Fig. 2, after treatment with NCTD for 24 h, NCTD induced significantly HDLEC apoptosis in vitro when compared with control group $(1.280 \pm 0.010$ vs. $16.380 \pm 1.400 \%, \mathrm{P}<0.05)$, with a dose- and time-dependent manner, i.e., apoptosis percent of HDLECs (total cells under right quadrant of cells) increased (FCM analysis, Fig. 2A); viable HDLECs decreased, apoptotic cells which presented bright blue or orange dyes, even with fine or fragmented nuclei increased (fluorescence microscopy observation, Fig. 2B), along with increase of NCTD concentration. In addition, Fig. $2 \mathrm{C}$ shows under electron microscope irregular cells with abundant microvilli, clear cell organelles, larger nucleus/cytoplast ratio, irregular nuclei and chromatin enrichment compared to the control group (Fig. 2Cc1); and decreased microvilli, golgiosome atrophy, mitochondria swelling, cytoplast vacuoles, nuclear shrinkage, chromosome condensation, chromatin aggregation and typical apoptosis bodies in NCTD $(2.5 \mu \mathrm{g} / \mathrm{ml})$ group (Fig. 2Cc2-c4). It is thus clear that NCTD induces significantly apoptosis of HLECs.

NCTD inhibits HLEC migration. The effects of NCTD on migration of the cultured HDLECs, i.e., cell migration distance onto the scraped areas and migrated cells were measured by scraping line method under an inversion microscope. As shown in Fig. 3, after treatment with NCTD for $24 \mathrm{~h}$ and along with increase of NCTD concentration, migrated cells $(11.5 \pm 3.4$, $17.7 \pm 2.8$ or $32.5 \pm 4.3$ vs. $56.3 \pm 5.2 \mathrm{n}, \mathrm{P}=0.000$; Fig. $3 \mathrm{Bb} 1$ ) onto the scraped areas were decreased, cell migration distance (75.6 $49.7,163.4 \pm 15.3$ or $258.7 \pm 28.7$ vs. $405.7 \pm 20.5 \mu \mathrm{m}, \mathrm{P}=0.000$; Fig. 3Bb2) was shortened significantly, when compared with control group. It was shown that NCTD inhibited significantly migration of HLECs in vitro, in a dose-dependent manner.

NCTD inhibits HLEC invasion. The effect of NCTD on invasion of the cultured HDLECs was measured by Matrigel invasion experiment. As shown in Fig. 4, HDLECs in control group passed more of the membrane and had more invasive capability in vitro; NCTD began to inhibit the invasion of HDLECs at the concentration of $5 \mu \mathrm{g} / \mathrm{ml}$ and as its concentration increased, their passing membrane cells markedly decreased, the trypan blue dyed cells, namely the dead passing-membrane cells obviously increased (P<0.01). At $50 \mu \mathrm{g} / \mathrm{ml}$ of NCTD, the invasive action of HDLECs was inhibited almost completely. Thus, NCTD inhibited significantly invasion of HLECs in a dose-dependent manner.

NCTD inhibits HLEC lymphatic tube formation. The lymphatic capillary-like structures (i.e., lymphangiogenesis) formed from the three-dimensional culture of HDLECs in vitro was observed by inverted phase-contrast light microscopy. As shown in Fig. 5, when seeded on the mixed fibrinogen gel for $24 \mathrm{~h}$, HDLECs started to paste the well walls, grew, spread out, formed cell groups composed of multi-angular or pseudopod cells (Fig. 5Aa1); formed tubular rudiment structure at the third day (Fig. 5Aa2); had some typical lymphatic capillary-like tubes, with 

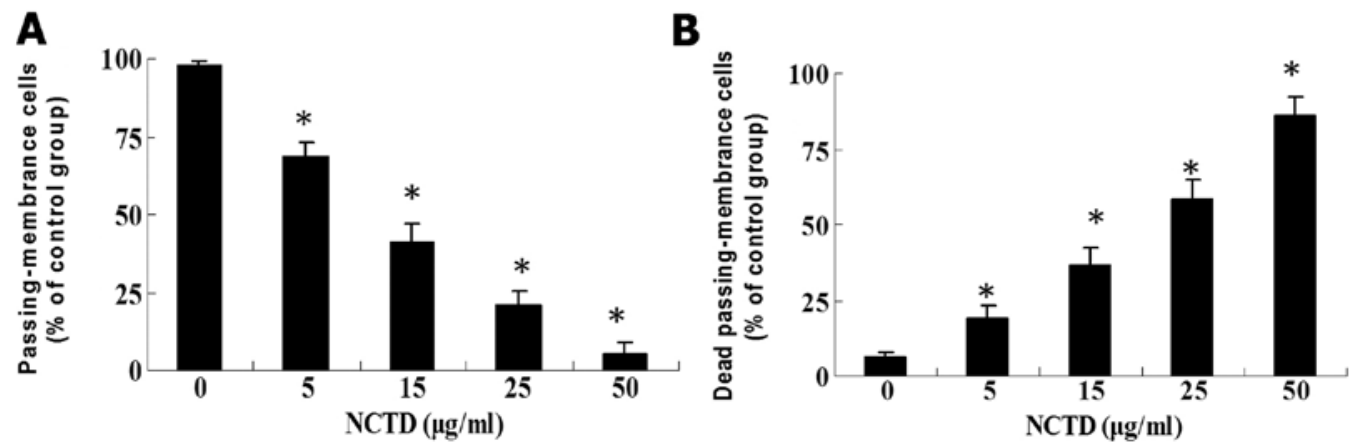

Figure 4. The inhibitory effect of NCTD on HDLEC invasion in vitro. Invasion assay of HDLECs was done by the Matrigel invasion experiment. (A) The histogram of passing membrane HDLECs. (B) The histogram of dead passing-membrane HDLECs. As its concentration increased, the passing membrane cells in NCTD group markedly decreased, the dead passing-membrane cells obviously increased, when compared with control group ("P<0.01, vs. control group).

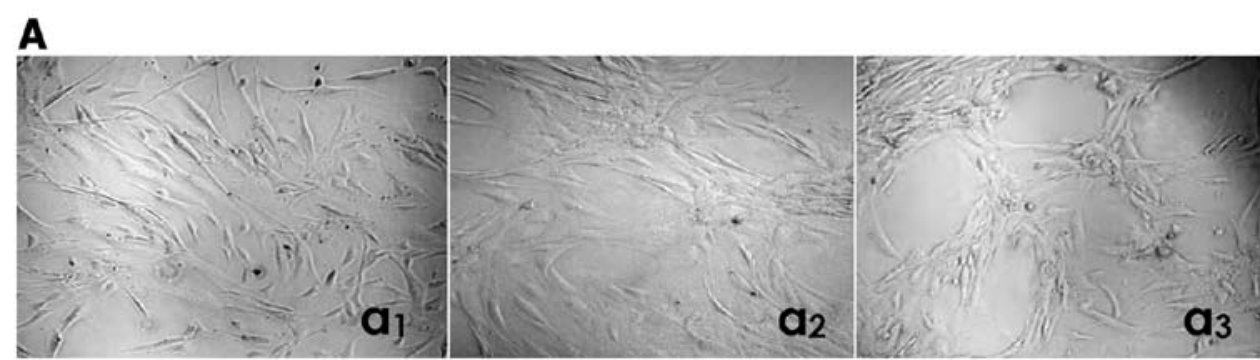

B
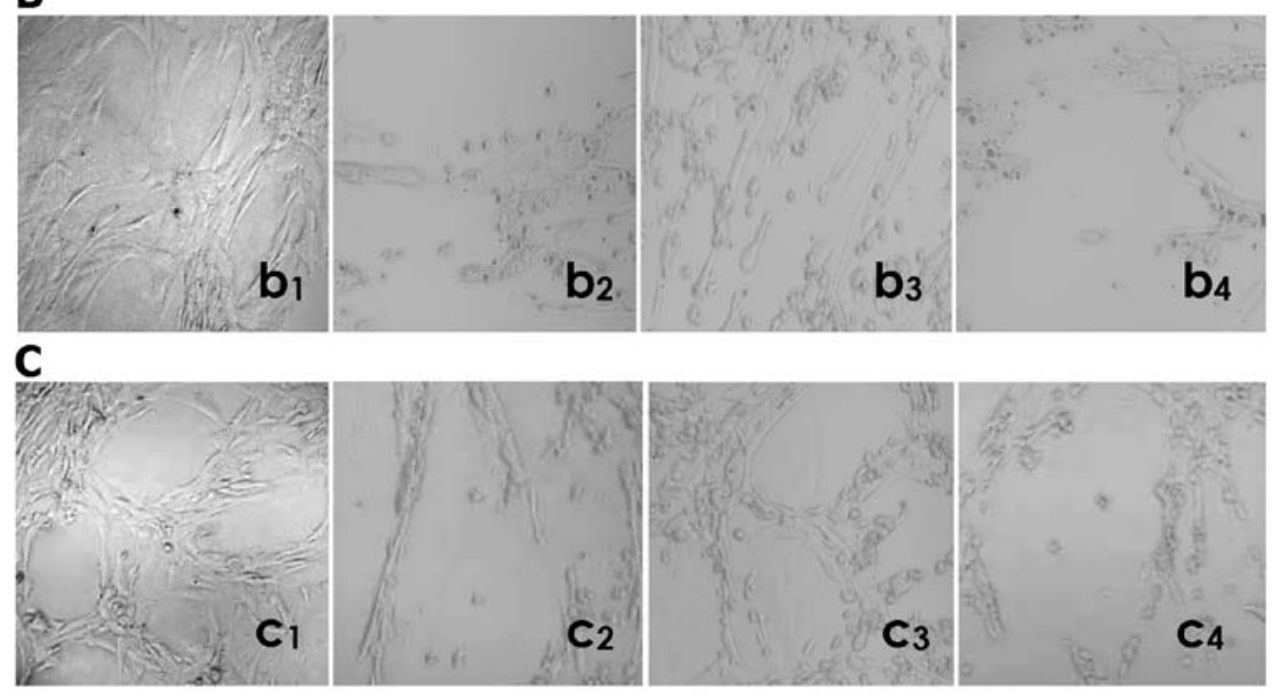

Figure 5. Lymphatic tube formation i.e., lymphangiogenesis of HDLECs in different groupsby inverted phase-contrast light microscopy (magnification x200) in vitro. (A) (in control group): when seeded on the mixed fibrinogen gel, HDLECs started to paste the wall of the well, grew, spread out, formed cell groups composed of multi-angular or pseudopod cells at $24 \mathrm{~h} \mathrm{(a1);} \mathrm{formed} \mathrm{tubular} \mathrm{rudiment} \mathrm{structure} \mathrm{at} \mathrm{the} \mathrm{third} \mathrm{day} \mathrm{(a2);} \mathrm{had} \mathrm{some} \mathrm{typical} \mathrm{lymphatic} \mathrm{tube} \mathrm{formation,}$ with obvious pipe walls, lumen and progressive branches (a3) after 1 week. (B) (at the second day in the process of lymphatic tube formation): in control group, HDLECs started to grow in the form of pasting the wall of well, to spread out and form tubular rudiment structure (b1); using NCTD (b2), mF4-31C1 (b3) or NCTD+mF4-31C1 (b4) for 2 days, HDLECs lost the capacity of the above lymphatic tube formation, with visible cell aggregation, floating, nuclear fragmentation, apoptosis and necrosis. (C) One week after lymphatic tube formation, there are some typical lymphatic tube structures in the control group (c1); the formed structure of lymphatic tubes was destroyed, with visible cell aggregation, floating, nuclear fragmentation, apoptosis and necrosis, after using NCTD (c2), mF4$31 \mathrm{C} 1$ (c3) or NCTD+mF4-31C1 (44) for 4 days.

obvious pipe walls, the lumen and progressive branches after 1 week (Fig. 5Aa3). At the second day in the process of lymphatic tube formation, HDLECs started to grow in the form of pasting the wall of the well, to spread out and form tubular rudimental structures in control group (Fig. 5Bb1); HDLECs lost the capacity of the above lymphatic tube formation, with visible cell aggregation, floating, nuclear fragmentation, apoptosis and necrosis, after using NCTD (Fig. 5Bb2), mF4-31C1 (Fig. 5Bb3) or NCTD+mF4-31C1 (Fig. 5Bb4) for 2 days. By counting the total number of cell clusters and branching of lymphatic tube formation, it was found that the lymphatic capillary-tube number in NCTD, mF4-31C1 or NCTD+mF4-31C1 group was less than that in the control group $(10.9 \pm 2.3,32.8 \pm 5.4$ or $9.8 \pm 1.5$, vs. $68.4 \pm 5.2$, all $\mathrm{P}<0.000$ ), while the lymphatic number 

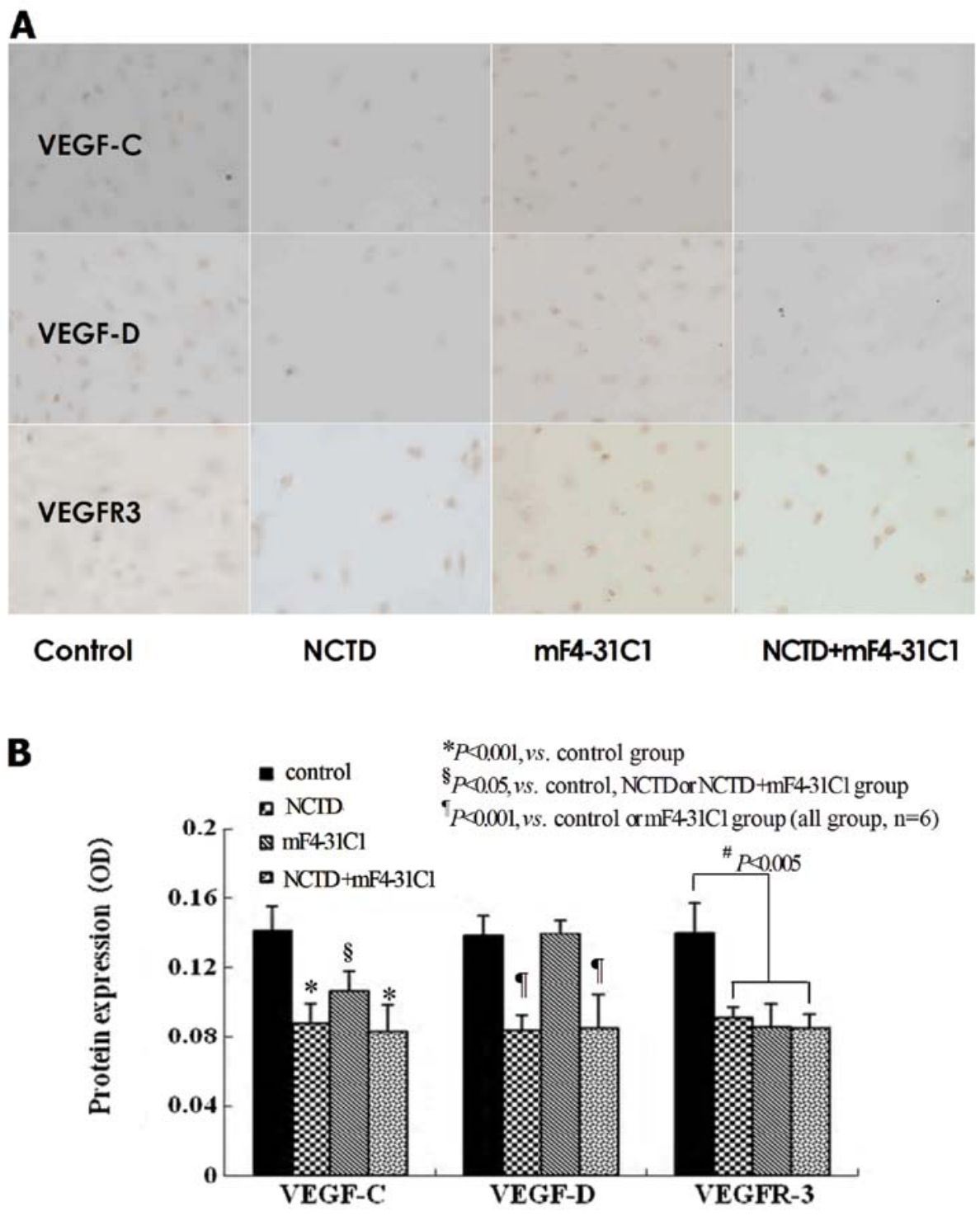

Figure 6. The expression of VEGF-C, VEGF-D and VEGFR-3 at protein (immunocytochemistry, streparidin-peroxidase staining method, magnification $\mathrm{x} 200$ ) in the lymphatic tube-formation of HDLECs in different groups in vitro. The expression of VEGF-C, VEGF-D or VEGFR-3 protein in NCTD group or NCTD+mF4-31C1 group was decreased significantly when compared with control group (P<0.001); but the expression of VEGF-C protein in NCTD or NCTD+mF4-31C1 group was lower than that of $\mathrm{mF} 4-31 \mathrm{C} 1$ group $(\mathrm{P}<0.05)$; and there was no statistical difference in VEGF-D expression between control group and $\mathrm{mF} 4-31 \mathrm{C} 1$ group.

in NCTD or NCTD+mF4-31C1 group was less than that in mF4-31C1 group $(10.9 \pm 2.3$ or $9.8 \pm 1.5$, vs. $32.8 \pm 5.4$, all $\mathrm{P}<0.01)$. One week after lymphatic tube formation, there are some typical lymphatic tube structures in the control group (Fig. 5Cc1); the formed structure of lymphatic tubes was destroyed, with visible cell aggregation, floating, nuclear fragmentation, apoptosis and necrosis, after using NCTD (Fig. 5Cc2), mF4-31C1 (Fig. 5Cc3) or NCTD+mF4-31C1 (Fig. 5C44) for 4 days. It was shown that NCTD or mF4-31C1 obviously inhibited and destroyed the forming of lymphangiogenesis and formed lymphangiogenesis from the 3-D culture of HDLECs in vitro, while this effect of NCTD or NCTD+mF4-31C1 was stronger. Thus, NCTD or mF4-31C1 effectively inhibits lymphatic tube formation of HLECs.

NCTD downregulates the expression of VEGF-C, VEGF-D and VEGFR-3 in the process of lymphatic tube-formation of HLECs.
VEGF-C, VEGF-D, VEGFR-3 at protein and mRNA levels in lymphangiogenesis on 3-D culture of HDLECs were measured by immunohistochemistry (streparidin-peroxidase staining method), western blotting and quantitative real-time polymerase chain reaction (QRT-PCR). As shown in Figs. 6 and 7, at protein level, the expression of VEGF-C, VEGF-D and VEGFR-3 in NCTD group or NCTD+mF4-31C1 group was decreased significantly when compared with control group $(\mathrm{P}<0.001)$; but the expression of VEGF-C in NCTD or NCTD+mF4-31C1 group was lower than that of $\mathrm{mF} 4-31 \mathrm{C} 1$ group $(\mathrm{P}<0.05)$; and there was no statistical difference in VEGF-D expression between control group and $\mathrm{mF} 4-31 \mathrm{C} 1$ group (Figs. 6 and 7A-C). At the mRNA level, the expression of VEGF-C, VEGF-D and VEGFR3 mRNAs was decreased significantly in all experimental groups when compared with control group; but the expression of VEGF-C mRNA in NCTD or NCTD+mF4-31C1 group was also lower than that of $\mathrm{mF} 4-31 \mathrm{C} 1$ group $(\mathrm{P}<0.05)$; 
A

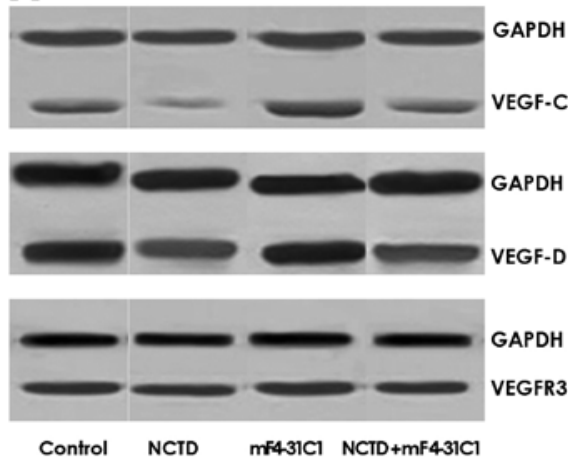

B

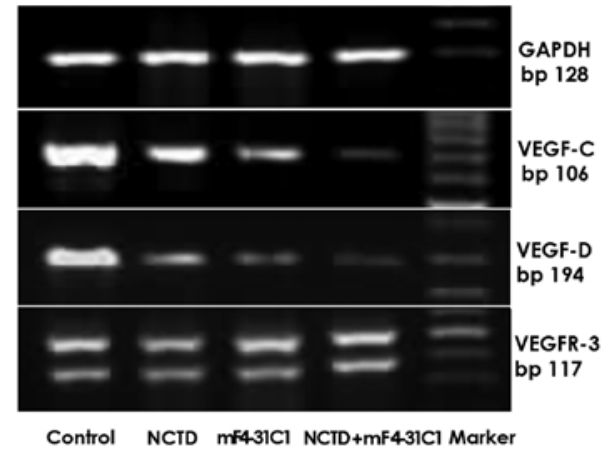

C

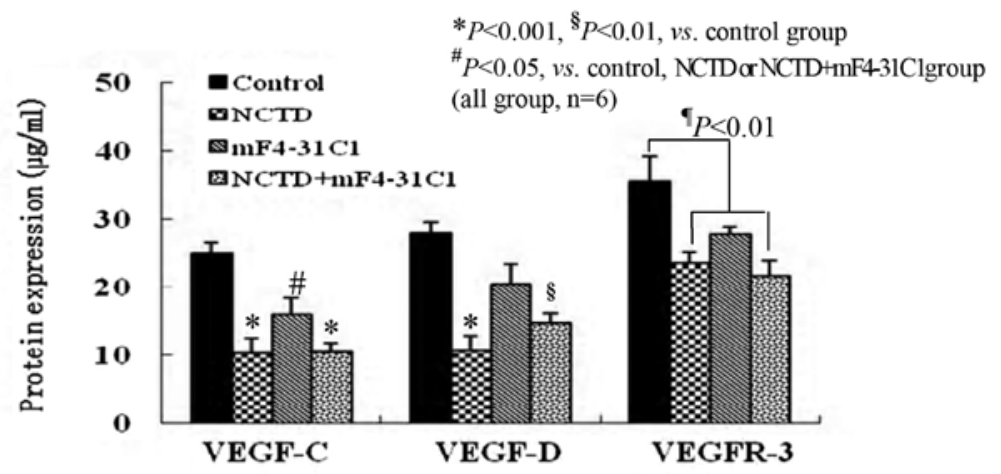

D

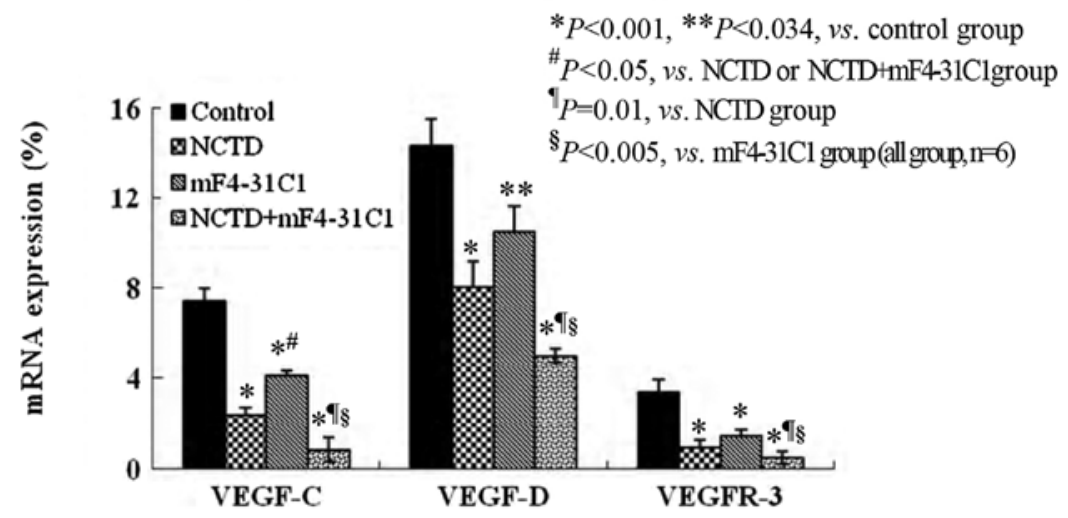

Figure 7. The expression of VEGF-C, VEGF-D and VEGFR-3 at protein and mRNA levels in the lymphatic tube-formation of HDLECs in different groups in vitro. (A and C) (Western blotting, Lowry method): at protein levels, the expression of VEGF-C, VEGF-D and VEGFR-3 in NCTD group or NCTD+mF4-31C1 group was decreased significantly when compared with control group $(\mathrm{P}<0.001)$; but the expression of VEGF-C in NCTD or NCTD+mF4-31C1 group was lower than that of $\mathrm{mF} 4-31 \mathrm{C} 1$ group $(\mathrm{P}<0.05)$; and there was no statistical difference in VEGF-D expression between control group and $\mathrm{mF} 4-31 \mathrm{C} 1$ group. (B and D) (QRT-PCR): at mRNA levels, the expression of VEGF-C, VEGF-D and VEGFR3 mRNAs was also decreased significantly in all experimental groups when compared with control group; but the expression of VEGF-C mRNA in NCTD or NCTD+mF4-31C1 group was lower than that of mF4-31C1 group $(\mathrm{P}<0.05)$; and the expression of VEGF-C, VEGF-D or VEGFR3 mRNAs in NCTD+mF4-31C1 group was significantly lower than those of mF4-31C1 $(\mathrm{P}<0.005)$ or $\mathrm{NCTD}(\mathrm{P}=0.01)$ group.

and the expression of VEGF-C, VEGF-D or VEGFR3 mRNAs in NCTD+mF4-31C1 group was significantly lower than those of mF4-31C1 $(\mathrm{P}<0.005)$ or NCTD $(\mathrm{P}=0.01)$ group (Fig. 7C and D). It was shown that NCTD downregulated the expression of VEGF-C, VEGF-D and VEGFR-3 at protein and mRNA levels in the process of lymphatic tube-formation of HLECs; $\mathrm{mF} 4-31 \mathrm{C} 1$ did not effect VEGF-D expression; the downregulation of VEGF-C, VEGF-D/VEGFR3 by the combined application of NCTD and mF4-31C1 can be enhanced. Thus, we believe that NCTD inhibit lymphangiogenesis in HLECs by simultaneously blocking VEGF-C, VEGF-D and VEGFR-3.

\section{Discussion}

The metastatic spread of tumor cells via the lymphatic vessels is a lethal aspect of cancer. Tumor-associated lymphatic vessels act as a conduit by which disseminating tumor cells access regional lymph nodes and form metastases (17). The presence of metastatic cells in the sentinel lymph node is a prognostic indicator and the degree of dissemination determines the therapeutic course of action (18). A growing body of evidence indicates that tumor lymphangiogenesis is a predictive indicator of metastasis to lymph nodes. According to the centrifugal 
theory of lymphangiogenesis, in the early stage of the development of lymphatics, lymph sacs develop independently by the further sprouting of venous endothelium and extend by the sprouting of endothelial cells into the surrounding tissues and organs to form local lymphatic capillary networks (19). In other words, lymphangiogenesis is the growth of newly formed lymphatic vessels; this process with multiple steps is similar to the well-known mechanism of angiogenesis: endothelial cell proliferation, migration, rearrangement and tube formation, along with degradation, reconstruction and production of extracellular matrix. Lymph node lymphangiogenesis and increased lymph flow through tumor-draining lymph nodes are speculated to actively promote metastasis via the lymphatics (20). Tumor- or stromal-secreted cytokines, such as VEGF-C and VEGF-D, bind to VEGF receptors on LECs and induce proliferation and growth of new lymphatic capillaries (21). Therefore, inhibition of tumor-associated lymphangiogenesis or its VEGF-C, -D/VEGF receptors may be a potential therapy for primary tumors and metastasis via the lymphatics.

In recent years, some drugs are used to treat tumors with the anti-lymphangiogenic mechanism. Researchers have focused on hot-spots of treating carcinoma by inhibition or destroying of tumor lymphatic tube formation early, i.e., lymphangiogenesis $(9,10,18)$. These lymphangiogenic inhibitors such as deguelin, endostar, silencing Id-1, liposomal honokiol, mF4-31C1, Ki23057, sVEGFR3-Ig, VEGFR31-Ig, artemisinin, etodolac, MMI270, CSDA and AZM475271 have been reported as adjuvant anti-lymphangiogenic and anti-tumor drugs against some metastatic cancers in experimental and in clinical setting (22-37). NCTD has been reported to possess potent anti-angiogenesis and antitumor properties in several cell lines and tumor models (11-16,38-41). However, it is still unclear whether NCTD effectively inhibits tumor-associated lymphangiogenesis and lymphatic metastasis. Here, we investigated the antilymphangiogenic effect of NCTD on HLECs. It was shown that NCTD significantly inhibited proliferation, migration, invasion, lymphatic tube formation of HLECs and induced apoptosis of HLECs (all $\mathrm{P}<0.01$ ), dose- and time-dependently $\left(\mathrm{IC}_{50} 6.8 \mu \mathrm{g} / \mathrm{ml}\right)$. Over the past few years, understanding of the cellular and molecular aspects of physiologic lymphangiogenesis and tumor-induced lymphangiogenesis has advanced. Proliferation of the lymphatics is an active biological behavior of tumor cells, with heterogeneity of interactions of tumor cells with lymphatic vessels in tumors and regional lymph system. Although lymphatic vessels constitute the most important channel of lymphatic spread, lymphatic endothelium is an interactive surface for cancer cells, and the ability of cancer cells to interact with the lymphatic endothelial cells is a key step in allowing them to invade the lymphatic system (20). In this study, we identified for the first time that NCTD inhibited lymphangiogenesis in HLECs in vitro. Thus, we believed that NCTD might be a potential target agent for lymphangiogenesis of HLECs, and the key of the antitumor properties or mechanisms.

Tumors promote lymphangiogenesis by secreting molecules (lymphangiogenic growth factors) from tumor cells and stromal cells that stimulate lymphatic endothelial cell growth (42). These lymphangiogenic growth factors include VEGF-A, VEGF-C, VEGF-D, PDGF, HGF, Ang-1, Ang-2, IGF-1/2 and FGF-2
(bFGF) (18). Of them, most important lymphangiogenic growth factors are VEGF-C, VEGF-D and their cognate receptor VEGFR-3 located on lymphatic endothelial cells (6-10,18-21). These molecules play an important role on lymphangiogenesis and distinguish subtypes in tumor metastasis. In xenotransplanted tumors, cancer cells transfected by VEGF-C gene induce the growth of functional lymphatics and result in hyperplastic vessels (43). VEGF-C not only induces the hyperplasia of peritumoral vessels, but also increases the volumetric flow rate of fluid in lymphatics that results in the increased delivery of tumor cells to the lymph node (44). Indeed, many other growth factors (FGF-2, Ang-1, VEGF-A, IGF-1, HGF) stimulate lymphangiogenesis indirectly through VEGF-C. VEGF-D also plays a role in the regulation of tumor lymphangiogenesis $(45,46)$. Functional autocrine stimulation of VEGF-D in cancer not only stimulates the proliferation of cancer cells and LECs, but also plays a role in the maintenance of anti-apoptotic characteristics of tumor-derived endothelial cells (20). Activation of VEGF-C/ VEGF-D/VEGFR-3 axis increases motility and invasiveness of LECs, promote formation of tumor lymphatics (lymphangiogenesis) (47). Most anti-lymphangiogenic pre-clinical studies to date have targeted the VEGF-C/VEGF-D/VEGFR-3 signaling pathway. A targeted approach to block pathways of lymphangiogenesis seems to be an attractive anticancer treatment strategy. These strategies have included targeting and knock down of lymphangiogenic ligands, targeting receptors on lymphatic endothelium and inhibiting tumor lymphangiogenesis with soluble receptors. The downmodulation of VEGF-C with stable RNAi transfection in murine breast cancer cells results in reduced tumor lymphangiogenesis and lymph node metastasis (48). Deguelin suppresses tumorassociated lymphangiogenesis and lymphatic metastasis in lung tumor model by downregulation of VEGF-D both in vitro and in vivo (22). Blocking the expression of VEGFR-3 using interference vector-based RNA interference inhibits tumor growth of colorectal cancer (29). Adeno-associated virus-mediated gene transfer of sVEGFR3-Fc potently blocks tumor-associated lymphangiogenesis and metastasis to the lymph nodes in human prostate and melanoma tumor models (49). mF4-31C1, a novel VEGFR-3 neutralizing antibody, potently antagonizes the binding of VEGF-C to VEGFR-3. Because blocking of VEGFR-3 using mF4-31C1 completely and specifically prevented both physiologically normal and tumor VEGF-C-enhanced lymphangiogenesis in the adult mouse tail skin model of lymphatic regeneration but had no effect on either blood angiogenesis or the survival or function of existing lymphatic vessels, targeting VEGFR-3 with the specific inhibitor blocked new lymphatic growth exclusively (26). In the present study, NCTD downregulated the expression of VEGF-C, VEGF-D and VEGFR-3 at protein and mRNA levels in the process of lymphatic tube-formation, i.e., lymphangiogenesis of HLECs. Because VEGF-C and VEGF-D are primarily lymphangiogenic factors, VEGF$\mathrm{C}$,-D/VEGFR axis or signal pathway seem probably the main target of the anti-lymphangiogenesis in physiological and pathological conditions, we may deduce that NCTD target and inhibit lymphangiogenesis in HLECs by simultaneous blocking and suppression of VEGF-C and -D/VEGFR-3 axis or signal pathway. The present findings may be of importance to explore the therapeutic strategy of NCTD as 
an anti-lymphangiogenic agent for tumor lymphangiogenesis and lymphatic metastasis. However, further experiments are needed to explore whether NCTD inhibits tumor lymphangiogenesis and lymphatic metastasis in tumor models, and whether it works through the same mechanism in vivo.

\section{Acknowledgements}

This study was supported by a grant from the National Nature Science Foundation of China (no. 81072004).

\section{References}

1. Achen MG and Stacker SA: Tumor lymphangiogenesis and metastatic spread - new players begin to emerge. Int J Cancer 119: 1755-1760, 2006.

2. Nagahashi M, Ramachandran S, Rashid OM and Takabe K: Lymphangiogenesis: a new player in cancer progression. World J Gastroenterol 16: 4003-4012, 2010.

3. Tobler NE and Detmar M: Tumor and lymph node lymphangiogenesis-impact on cancer metastasis. J Leukoc Biol 80: 691-696, 2006.

4. Liersch R, Biermann C, Mesters RM and Berdel WE: Lymphangiogenesis in cancer: current perspectives. Recent Results Cancer Res 180: 115-135, 2010.

5. Sleeman JP and Thiele W: Tumor metastasis and the lymphatic vasculature. Int J Cancer 125: 2747-2756, 2009.

6. Veikkola T, Jussila L, Makinen T, Karpanen T, Jeltsch M, Petrova TV, Kubo H, Thurston G, McDonald DM, Achen MG Stacker SA and Alitalo K: Signaling via vascular endothelial growth factor receptor-3 is sufficient for lymphangiogenesis in transgenic mice. EMBO J 20: 1223-1231, 2001.

7. Joukov V, Sorsa T, Kumar V, Jeltsch M, Claesson-Welsh L, Cao Y, Saksela O, Kalkkinen N and Alitalo K: Proteolytic processing regulates receptor specificity and activity of VEGF-C. EMBO J 16: 3898-3911, 1997.

8. Siegfried G, Basak A, Cromlish JA, Benjannet S, Marcinkiewicz J, Chrétien M, Seidah NG and Khatib AM: The secretory proprotein convertases furin, PC5, and PC7 activate VEGF-C to induce tumorigenesis. J Clin Invest 111: 1723-1732, 2003

9. Kowanetz M and Ferrara N: Vascular endothelial growth factor signaling pathways: therapeutic perspective. Clin Cancer Res 12 : 5018-5022, 2006.

10. Wissmann C and Detmar M: Pathways targeting tumor lymphangiogenesis. Clin Cancer Res 12: 6865-6868, 2006.

11. Ho YP, To KK, Au-Yeung SC, Wang X, Lin G and Han X: Potential new antitumor agents from an innovative combination of demethylcantharidin, a modified traditional Chinese medicine, with a platinum moiety. J Med Chem 44: 2065-2068, 2001

12. Deng L and Tang S: Norcantharidin analogues: a patent review (2006-2010). Expert Opin Ther Pat 21: 1743-1753, 2011.

13. Fan YZ, Fu JY, Zhao ZM and Chen CQ: Inhibitory effect of norcantharidin on the growth of human gallbladder carcinoma GBC-SD cells in vitro. Hepatobiliary Pancreat Dis Int 6: 72-80, 2007.

14. Fan YZ, Zhao ZM, Fu JY, Chen CQ and Sun W: Norcantharidin inhibits growth of human gallbladder carcinoma xenografted tumors in nude mice by inducing apoptosis and blocking the cell cycle in vivo. Hepatobiliary Pancreat Dis Int 9: 414-422, 2010.

15. Chen YJ, Tsai YM, Kuo CD, Ku KL, Shie HS and Liao HF: Norcantharidin is a small-molecule synthetic compound with anti-angiogenesis effect. Life Sci 85: 642-651, 2009.

16. Zhang JT,Fan YZ, Chen CQ,Zhao ZM and Sun W: Norcantharidin: a potential antiangiogenic agent for gallbladder cancers in vitro and in vivo. Int J Oncol 40: 1501-1514, 2012.

17. Achen MG and Stacker SA: Molecular control of lymphatic metastasis. Ann NY Acad Sci 1131: 225-234, 2008.

18. Zwaans BM and Bielenberg DR: Potential therapeutic strategies for lymphatic metastasis. Microvasc Res 74: 145-158, 2007.

19. Kotani M: The lymphatics and lymphoreticular tissues in relation to the action of sex hormones. Arch Histol Cytol 53 (Suppl): 1-76, 1990.

20. Zhang Z, Helman JI and Li LJ: Lymphangiogenesis, lymphatic endothelial cells and lymphatic metastasis in head and neck cancer - a review of mechanisms. Int J Oral Sci 2: 5-14, 2010.
21. Nathanson SD: Insights into the mechanisms of lymph node metastasis. Cancer 98: 413-423, 2003.

22. Hu J, Ye H, Fu A, Chen X, Wang Y, Chen X, Ye X, Xiao W, Duan X, Wei Y and Chen L: Deguelin - an inhibitor to tumor lymphangiogenesis and lymphatic metastasis by downregulation of vascular endothelial cell growth factor-D in lung tumor model. Int J Cancer 127: 2455-2466, 2010.

23. Dong X, Zhao X, Xiao T, Tian H and Yun C: Endostar, a recombined humanized endostatin, inhibits lymphangiogenesis and lymphatic metastasis of lewis lung carcinoma xenograft in mice. Thorac Cardiovasc Surg 59: 133-136, 2011.

24. Dong Z, Wei F, Zhou C, Sumida T, Hamakawa H, Hu Y and Liu S: Silencing Id-1 inhibits lymphangiogenesis through downregulation of VEGF-C in oral squamous cell carcinoma. Oral Oncol 47: 27-32, 2011.

25. Wen J, Fu AF, Chen LJ, Xie XJ, Yang GL, Chen XC, Wang YS, Li J, Chen P, Tang MH, Shao XM, Lu Y, Zhao X and Wei YQ: Liposomal honokiol inhibits VEGF-D-induced lymphangiogenesis and metastasis in xenograft tumor model. Int J Cancer 124: 2709-2718, 2009.

26. Pytowski B, Goldman J, Persaud K, Wu Y, Witte L, Hicklin DJ, Skobe M, Boardman KC and Swartz MA: Complete and specific inhibition of adult lymphatic regeneration by a novel VEGFR-3 neutralizing antibody. J Natl Cancer Inst 97: 14-21, 2005.

27. Rinderknecht M, Villa A, Ballmer-Hofer K, Neri D and Detmar M: Phage-derived fully human monoclonal antibody fragments to human vascular endothelial growth factor-C block its interaction with VEGF receptor-2 and 3. PLoS One 5: e11941, 2010.

28. Zhang D, Li B, Shi J, Zhao L, Zhang X, Wang C, Hou S, Qian W, Kou G, Wang H and Guo Y: Suppression of tumor growth and metastasis by simultaneously blocking vascular endothelial growth factor (VEGF)-A and VEGF-C with a receptor-immunoglobulin fusion protein. Cancer Res 70: 2495-2503, 2010.

29. Lui Z, Ma Q, Wang X and Zhang Y: Inhibiting tumor growth of colorectal cancer by blocking the expression of vascular endothelial growth factor receptor 3 using interference vector-based RNA interference. Int J Mol Med 25: 59-64, 2010.

30. Yashiro M, Shinto O, Nakamura K, Tendo M, Matsuoka T, Matsuzaki T, Kaizaki R, Ohira M, Miwa A and Hirakawa K: Effects of VEGFR-3 phosphorylation inhibitor on lymph node metastasis in an orthotopic diffuse-type gastric carcinoma model. Br J Cancer 101: 1100-1106, 2009.

31. Guo B, Zhang Y, Luo G, Li L and Zhang J: Lentivirus-mediated small interfering RNA targeting VEGF-C inhibited tumor lymphangiogenesis and growth in breast carcinoma. Anat Rec 292: 633-639, 2009.

32. Wang J, Zhang B, Guo Y, Li G, Xie Q, Zhu B, Gao J and Chen Z: Artemisinin inhibits tumor lymphangiogenesis by suppression of vascular endothelial growth factor C. Pharmacology 82: 148-155, 2008.

33. Iwata C, Kano MR, Komuro A, Oka M, Kiyono K, Johansson E, Morishita Y, Yashiro M, Hirakawa K, Kaminishi M and Miyazono K: Inhibition of cyclooxygenase-2 suppresses lymph node metastasis via reduction of lymphangiogenesis. Cancer Res 67: 10181-10189, 2007.

34. Cao G, Wu JX and Wu QH: Low molecular weight heparin suppresses lymphatic endothelial cell proliferation induced by vascular endothelial growth factor $\mathrm{C}$ in vitro. Chin Med J 122: 1570-1574, 2009.

35. Nakamura ES, Koizumi K, Kobayashi M and Saiki I: Inhibition of lymphangiogenesis-related properties of murine lymphatic endothelial cells and lymph node metastasis of lung cancer by the matrix metalloproteinase inhibitor MMI270. Cancer Sci 95: 25-31, 2004.

36. Matsumoto G, Yajima N, Saito H, Nakagami H, Omi Y, Lee U and Kaneda Y: Cold shock domain protein A (CSDA) overexpression inhibits tumor growth and lymph node metastasis in a mouse model of squamous cell carcinoma. Clin Exp Metastasis 27: $539-547,2010$.

37. Ischenko I, Seeliger H, Camaj P, Kleespies A, Guba M, Eichhorn ME, Jauch KW and Bruns CJ: Src tyrosine kinase inhibition suppresses lymphangiogenesis in vitro and in vivo. Curr Cancer Drug Targets 10: 546-553, 2010.

38. An WW, Wang MW, Tashiro S, Onodera S and Ikejima T: Norcantharidin induces human melanoma A375-S2 cell apoptosis through mitochondrial and caspase pathways. J Korean Med Sci 19: 560-566, 2004

39. Yi SN, Wass J, Vincent $\mathrm{P}$ and Iland $\mathrm{H}$ : Inhibitory effect of norcantharidin on K562 human myeloid leukemia cells in vitro. Leuk Res 15: 883-886, 1991. 
40. Yang PY, Chen MF, Tsai CH, Hu DN, Chang FR and Wu YC: Involvement of caspase and MAPK activities in norcantharidininduced colorectal cancer cell apoptosis. Toxicol In Vitro 24: 766-775, 2010.

41. Chen YJ, Kuo CD, Tsai YM, Yu CC, Wang GS and Liao HF: Norcantharidin induces anoikis through Jun-N-terminal kinase activation in CT26 colorectal cancer cells. Anticancer Drugs 19: 55-64, 2008

42. McColl BK, Loughran SJ, Davydova N, Stacker SA and Achen MG: Mechanisms of lymphangiogenesis: targets for blocking the metastatic spread of cancer. Curr Cancer Drug Targets 5: 561-571, 2005.

43. Cohen-Kaplan V, Naroditsky I, Zetser A, Ilan N, Vlodavsky I and Doweck I: Heparanase induces VEGF C and facilitates tumor lymphangiogenesis. Int J Cancer 123: 2566-2573, 2008.

44. Hoshida T, Isaka N, Hagendoorn J, di Tomaso E, Chen YL, Pytowski B, Fukumura D, Padera TP and Jain RK: Imaging steps of lymphatic metastasis reveals that vascular endothelial growth factor-C increases metastasis by increasing delivery of cancer cells to lymph nodes: therapeutic implications. Cancer Res 66 8065-8075, 2006.

45. Bierer S, Herrmann E, Kopke T, Neumann J, Eltze E, Hertle L and Wülfing C: Lymphangiogenesis in kidney cancer: expression of VEGF-C, VEGF-D and VEGFR-3 in clear cell and papillary renal cell carcinoma. Oncol Rep 20: 721-725, 2008.
46. Choi JH, Oh YH, Park YW, Baik HK, Lee YY and Kim IS: Correlation of vascular endothelial growth factor-D expression and VEGFR-3-positive vessel density with lymph node metastasis in gastric carcinoma. J Korean Med Sci 23: 592-597, 2008.

47. Su JL, Yen CJ, Chen PS, Chuang SE, Hong CC, Kuo IH, Chen HY, Hung MC and Kuo ML: The role of the VEGF-C/VEGFR-3 axis in cancer progression. Br J Cancer 96: 541-545, 2007.

48. Chen Z, Varney ML, Backora MW, Cowan K, Solheim JC, Talmadge JE and Singh RK: Down-regulation of vascular endothelial cell growth factor-C expression using small interfering RNA vectors in mammary tumors inhibits tumor lymphangiogenesis and spontaneous metastasis and enhances survival. Cancer Res 65: 9004-9011, 2005.

49. Lin J, Lalani AS, Harding TC, Gonzalez M, Wu WW, Luan B, Tu GH, Koprivnikar K, VanRoey MJ, He Y, Alitalo K and Jooss $\mathrm{K}$ : Inhibition of lymphogenous metastasis using adenoassociated virus-mediated gene transfer of a soluble VEGFR-3 decoy receptor. Cancer Res 65: 6901-6909, 2005. 